\section{METHYLENE BLUE REMOVAL USING COCONUT SHELL BIOCHAR SYNTHESIZED THROUGH MICROWAVE-ASSISTED PYROLYSIS}

\author{
Dwi Nuryana ${ }^{a}$ Muhammad Fahrul Rahman Alima, Maizatulakmal \\ Yahayub, Muhammad Abbas Ahmad Zainib, Raja Safazliana Raja \\ Sulongb, Muhammad Fakhrul Syukri Abd Azizb, Haniif \\ Prasetiawana, Zainul Akmar Zakariab, Ratna Dewi \\ Kusumaningtyasa*
}

aChemical Engineering Department, Faculty of Engineering, Universitas Negeri Semarang, Kampus Sekaran, Gunungpati, Semarang 50229 Indonesia

bSchool of Chemical and Energy Engineering (FCEE), Faculty of Engineering, Universiti Teknologi Malaysia, 81310 UTM Johor Bahru, Johor, Malaysia
Article history

Received

30 October 2019

Received in revised form

24 June 2020

Accepted

28 June 2020

Published online

27 August 2020

*Corresponding author ratnadewi.kusumaningtya s@mail.unnes.ac.id
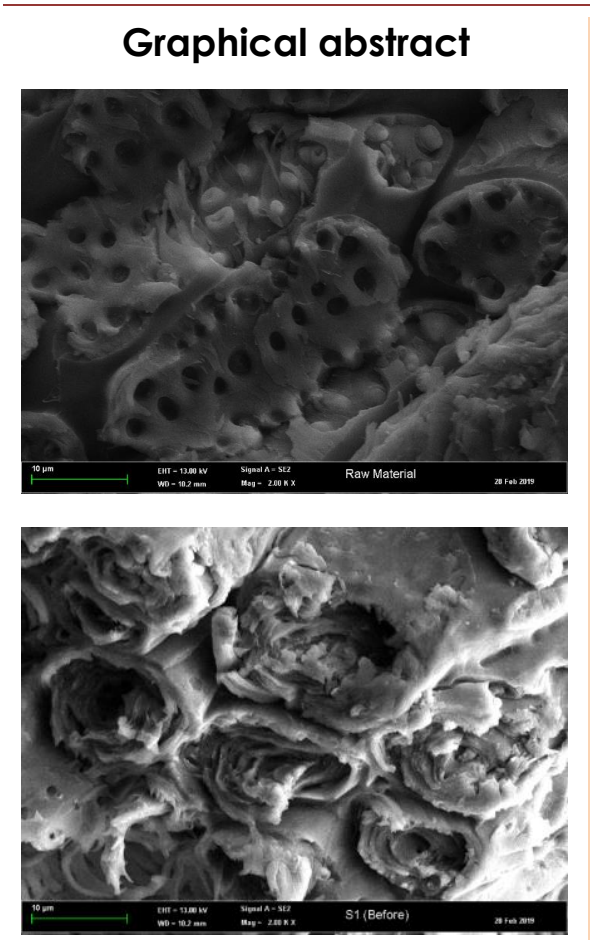

\begin{abstract}
Indonesia is the world's second largest producer of coconut. This at the same time resulted in huge generation of coconut shell waste that need to be properly managed to prevent environmental contamination such as water, air and soil pollution. Current techniques of physical and thermal processing are time and energy consuming. This study reports on the conversion of coconut shell biomass into biochar using microwave-assisted pyrolysis (MAP). The MAP processes were carried out at different microwave power (550-650 W) and residence time (15-25 minutes). Two of the highest biochar yields were obtained at $550 \mathrm{~W}$ with the residence times of 15 minutes (91.31 wt\%, termed as S1) and 20 minutes (83.88 wt\%, termed as S2), respectively. Both values were higher than biochar yield obtained using conventional pyrolysis process i.e. $30.10 \mathrm{w}+\%$. Both S1 and S2 showed considerable capacity to remove $0.6875 \mathrm{mg}^{-1}$ and $0.5165 \mathrm{mg}^{-1} \mathrm{~g}^{-1}$ methylene blue which had the initial concentration of $25 \mathrm{mg} \cdot \mathrm{L}^{-1}$. The adsorption efficiencies of S1 and S2 biochars were $55.00 \%$ and $41.32 \%$, respectively. Results obtained from the FTIR, FESEM and BET analysis also supported the methylene blue removal properties of both S1 and S2, respectively. As a conclusion, coconut shell showed potential as a useful raw material to produce biochar that can be used for methylene blue removal from solution. Nevertheless, more investigation need to be carried out prior to commercialization venture of the coconut-shell based biochar.
\end{abstract}

Keywords: Coconut, Biochar, Microwave, Pyrolysis, Methylene blue

\begin{abstract}
Abstrak
Indonesia merupakan pengeluar kelapa kedua terbesar di dunia. Hal ini turut menyebabkan penghasilan sisa tempurung kelapa yang besar yang memerlukan pengurusan sewajarnya bagi mengelakkan pencemaran alam sekitar seperti air, udara dan tanah. Teknik pemprosesan fizikal dan terma yang digunakan sekarang memerlukan penggunaan tenaga dan masa yang tinggi. Kajian ini melaporkan penghasilan biochar dari biomas tempurung kelapa dengan menggunakan kaedah pirolisis berbantukan-gelombang mikro (PGM). Proses PGM telah dijalankan pada kuasa gelombang mikro (550-650 W) dan masa penahanan (15-25 minit) yang berbeza. Dua hasil biochar tertinggi telah diperolehi pada $550 \mathrm{~W}$ dengan masa penahanan 15 minit (91.31 wt\%, dilabel sebagai S1) dan 20 minit (83.88 wt\%, dilabel
\end{abstract}


sebagai S2), masing-masing. Kedua-dua nilai adalah lebih tinggi dari hasil biochar yang diperolehi menggunakan proses pirolisis konvensional i.e. $30.10 \mathrm{w}$ †. Kedua-dua S1 dan S2 menunjukkan kapasiti untuk menjerap 0.6875 mg.g-1 dan 0.5165 mg.g-1 metilena biru pada kepekatan awal $25 \mathrm{mg}$.L-1. Efisiensi penjerapan biochar S1 dan S2 adalah $55.00 \%$ dan $41.32 \%$, masing-masing. Keputusan yang diperolehi dari analisis FTIR, FESEM dan BET turut menyokong penjerapan metilena biru oleh kedua-dua S1 dan S2. Sebagai kesimpulan, tempurung kelapa menunjukkan potensi yang baik untuk digunakan sebagai bahan mentah bagi penghasilan biochar yang boleh digunakan bagi menjerap metilena biru dari larutan. Walau bagaimanapun, lebih banyak kajian perlu dilakukan sebelum usaha pengkomersilan biochar berdasarkan tempurung kelapa ini boleh diteruskan.

Keywords: Kelapa, Biochar, Gelombang mikro, Pirolisis, Metilena biru

(c) 2020 Penerbit UTM Press. All rights reserved

\subsection{INTRODUCTION}

Coconut (Cocos nucifera) is the important crop estate commodity in tropical region, especially for the countries which belong to the Asia and Pacific Coconut Commodity (APCC). Among the world's leader in coconut production are Indonesia, Philippines, India, Brazil, and Sri Lanka. In Indonesia, coconut commodity plays an important role in agricultural sector since it is one of the main tree crop estates of the nation which significantly supports the country's economy. In this country, coconut has been utilized for many commercial purposes, especially for making copra and for the production of oil and food products. In 2016, the coconut production area was 3,544,002 hectares with a total production of 2,922,584 tons [1]. An old coconut fruit consists of four main components, namely coir, coconut shell, coconut meat, and coconut water. Generally, mature coconut fruit consists of four main components, viz. coir (35\%), coconut shell (12\%), coconut meat (28\%), and coconut water (25\%) [2]. This data implies the high volume of coconut commodity wastes, such as coconut shell, as a consequence of the high production of coconut commodity.

Plentiful coconut shell waste will cause environmental problem if it is not treated appropriately. When it is burned in open air, it will result in $\mathrm{CO}_{2}$ and methane emission, which are among the primary green-house gases in Earth's atmosphere. In fact, coconut shell waste is lignocellulosic biomass which can be derived into various valuable products, such as biooil [3, 4], concrete [5], silver nanoparticles for antibacterial [6], syngas, biochar, tar [7, 8], and activated carbon [9]. However, in Indonesia, coconut shell waste has not been optimally utilized for valuable products. Only a portion of the coconut waste has been commercially used for making briquette, charcoal, liquid smoke and handicraft, and the rest is only burned or thrown into the environment, causing pollution problem. Thus, the effort to enhance the coconut shell conversion into valuable and commercial products is crucial for reducing the environmental problem.
Biochar is among the interesting and prospective utilization of coconut shell at commercial scale. The most common process of biochar synthesis from biomass is through thermochemical conversion in the absence or in the limited condition of oxygen. The amount of oxygen is controlled to evade the extreme biomass oxidation [10]. The conventional thermochemical processes to convert biomass to biochar are pyrolysis (slow, intermediate, fast, and torrefaction), gasification and carbonization. However, the conventional pyrolysis process shows drawback in term of the long residence time of reaction, which triggers the disadvantage in economic aspect.

One of the prospective intensification processes of biomass thermochemical conversion is microwave assisted pyrolysis (MAP) technology [11]. MAP uses the microwave energy as heating source. Compared to the conventional pyrolysis which is use conventional heating sources, for instance electric heater or gas heater, MAP is more efficient [12]. Reddy et al. has also reported that MAP provides a rapid, selective, and non-contacting energy transfer [13]. MAP has recently applied for several process of decomposing biomass or other complex materials into various products, such as the conversion of rise husk to biochar [12], fiberboard to biochar [14], coal to blue-coke, coal-tar, and pyrolysis water [15], waste plastics and used cooking oil to liquid oil [16], bamboo into carbon fiber [17], Lignin to bio-oil [18], palm oil fiber to liquid oil [19] and Laminaria digitata seaweed to bio-oil [20]. Nonetheless, the application of MAP for converting coconut shell into biochar has not been investigated yet.

This study is the first to explore the application of microwave-assisted pyrolysis (MAP) technology for the production of biochar from coconut shell biomass. The specific purposes of this work are: 1) to evaluate the effect of main parameters (residence time and power of the microwave assisted pyrolysis of coconut shell on the biochar yield; 2) evaluating the methylene blue adsorption on coconut shell biochar; 3) characterization of coconut shell biochar to determine its properties. 


\subsection{METHODOLOGY}

\subsection{Materials}

In this study, coconut shell of Kelapa Dalam Bojong Bulat variety (Cocos nucifera) obtained from Bantul City, Indonesia was used as the feedstock for biochar production. This biomass has water and ash contents of $9.99 \%$ and $0.38 \%$, respectively. Methylene blue (C.I. 52015) from Merck, Germany was used to test the adsorption performance of coconut shell biochar. As a control, commercial activated carbon granule (C1452-32112392) obtained from HmBG Chemicals, Malaysia was also employed for methylene blue adsorption.

\subsection{Methods}

\subsubsection{Pretreatment}

Prior to the pyrolysis process, coconut shells were cleaned to remove the impurities and fibers. To reduce the water content, coconut shells were then dried under the sunlight for 7 days. The dried coconut shells were subsequently reduced in size by using hammer mills. Afterwards, sieving process was performed to obtain the coconut shell with the uniform size of $1.18-2.00 \mathrm{~mm}$. The small size coconut shells were dried in the oven for 24 hours before the MAP process was carried out.

\subsubsection{Microwave Assisted Pyrolysis (MAP)}

MAP was carried out using dried coconut shells (10g) at various microwave power $(550,600,650 \mathrm{~W})$ between 15-25 minutes (Figure 1). The operation condition for each sample is shown in Table 1.

Table 1 Operation Condition for Each Biochar Sample

\begin{tabular}{ccc}
\hline Sample & $\begin{array}{c}\text { Power } \\
\text { (W) }\end{array}$ & $\begin{array}{c}\text { Residence Time } \\
\text { (Minute) }\end{array}$ \\
\hline S1 & 550 & 15 \\
S2 & 550 & 20 \\
S3 & 550 & 25 \\
S4 & 600 & 15 \\
S5 & 600 & 20 \\
S6 & 600 & 25 \\
S7 & 650 & 15 \\
S8 & 650 & 20 \\
S9 & 650 & 25 \\
(+) Control & & \\
(-) Control & & \\
\hline
\end{tabular}

To measure the biochar surface temperature, as soon as the MAP process finished, the microwave door was opened and the biochar surface was shot using an infrared thermometer gun. The yield of biochar obtained was determined using Equation (1).

$$
\% \text { Yield }=\frac{W_{f}}{W_{0}} \times 100
$$

where $W_{f}$ is the biochar mass and $W_{0}$ is the mass of coconut shells as raw material.

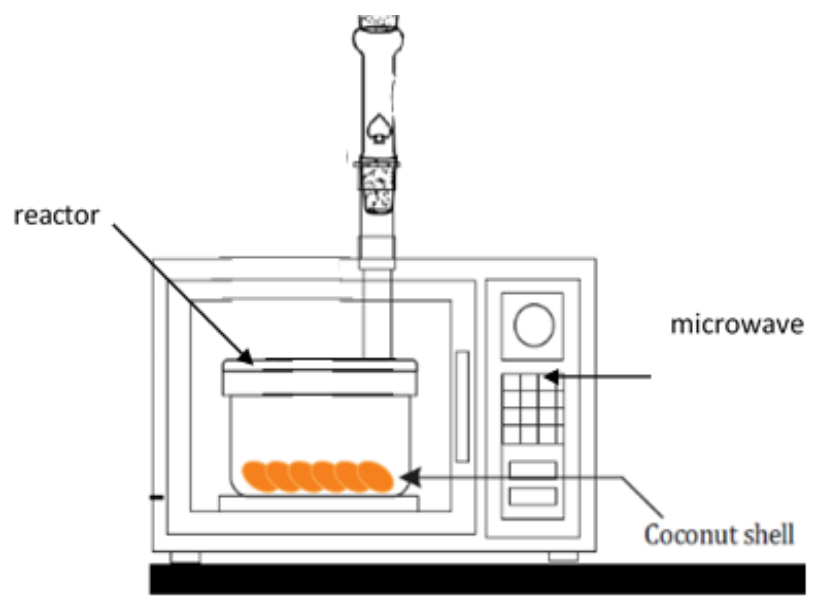

Figure 1 Schematic diagram of the MAP process

\subsubsection{Adsorption Test}

The methylene blue (MB) adsorption studies were carried out in a series of $500 \mathrm{~mL}$ Erlenmeyer flasks containing a mixture of $25 \mathrm{mg} \cdot \mathrm{L}^{-1}$ of $\mathrm{MB}$ and $1 \mathrm{~g}$ of biochar in a final volume of $50 \mathrm{~mL}$. Adsorption tests were carried out for the 9 samples of biochars which were produced from the different MAP conditions. As control, adsorption process with the similar condition which was conducted using commercial activated carbon was used as the positive $(+)$ control, and the solution which was not underwent adsorption process was employed for the negative (-) control. The mixtures were shaken on an orbital shaker (Certomat$\mathrm{R}, \mathrm{B}$. Braun) at $100 \mathrm{rpm}$ for 4 hours. The residual and final concentrations of $M B$ were determined using a UV-vis spectrophotometer (UV-1800, ShimadzU) with the wavelength of $660 \mathrm{~nm}$. The amount of methylene blue adsorbed (mg.g-1 biochar) was ascertained using Equations 2 and 3.

$$
\begin{aligned}
& \% \text { Removal efficiency }=\frac{\mathrm{C}_{0}-\mathrm{C}_{\mathrm{e}}}{\mathrm{C}_{0}} \times 100 \\
& \text { Adsorption amount }\left(\mathrm{mg} \cdot \mathrm{g}^{-1}\right)=\frac{\mathrm{C}_{0}-\mathrm{C}_{\mathrm{e}}}{\mathrm{V} / \mathrm{m}}
\end{aligned}
$$

where $\mathrm{C}_{0}$ is initial concentration of methylene blue (25 mg. $\left.\mathrm{L}^{-1}\right), \mathrm{C}_{e}$ is the final concentration of methylene blue after the adsorption process $\left(\mathrm{mg}^{\mathrm{L}} \mathrm{L}^{-1}\right), \mathrm{V}$ is volume of methylene blue $(\mathrm{L})$, and $\mathrm{m}$ is mass of biochar (g). Volume of methylene blue used in the experiment was $0.05 \mathrm{~L}$.

\subsubsection{Characterization}

The raw coconut shell and the biochar samples before and after being used for $M B$ adsorption process were characterized for functional group 
(FTIR), surface morphology (FESEM) and surface area properties (BET) using the following procedures. Fourier Transform Infrared analysis (FTIR) was used to identify the functional groups on the surface of biochar using (Nicolet is 10, Thermo Scientific). The biochar samples were directly scanned at a resolution of $4 \mathrm{~cm}^{-1}$ measured between $400-4000 \mathrm{~cm}^{-1}$.

The FESEM analysis was used to study the morphological characteristics of biochar samples. This analysis was carried out using Zeiss Supra 40VP, Germany at the Materials Science laboratory, Faculty of Engineering, Universiti Teknologi Malaysia (UTM). SEM holder integrated with electrically conducting carbon adhesive tabs was used to mount the samples. Then, a $20 \mathrm{~nm}$ gold layer was coated to the samples before viewing under the electron microscope.

The surface area determination for biochar was carried out using surface area and pore analyser (Surfer, Thermo Scientific) through multiple-point nitrogen $\left(\mathrm{N}_{2}\right)$ adsorption-desorption isotherm at 77K. In this work, the Brunaver, Emmett and Teller (BET) technique was applied to find out the specific surface area. The micropore surface area and volume were identified by the Dubinin and Raduskevich method, while Barret-Joyner-Halenda (BJH) method was used to reveal the mesopore surface area and volume. Furthermore, average Pore size was determined using Gurvitch method.

\subsection{RESULTS AND DISCUSSION}

Raw material for biochar production in this work was Indonesian coconut shell which has water contents of $9.99 \%$. The water content was comparable to the data reported in the literature, which are $5.7 \%$ [21], $8.44 \%$ [22], and $10.53 \%$ [23]. The low water content in raw material can increases the carbon (C) content of the char [24]. The ash content of the coconut shell was $0.38 \%$. It was in the similar order of magnitude to the result reported by Windeatt et al. [21] and Yang et al. [23], which demonstrated the ash content of $0.6 \%$. The low ash content in raw material can increases the carbon (C) content of the char since the high content of ash will inhibit the aromatic carbon formation [25]. This raw material characteristic demonstrated that coconut shell is suitable to be used for biochar synthesis. The coconut shell used in this work is shown in Figure 2.

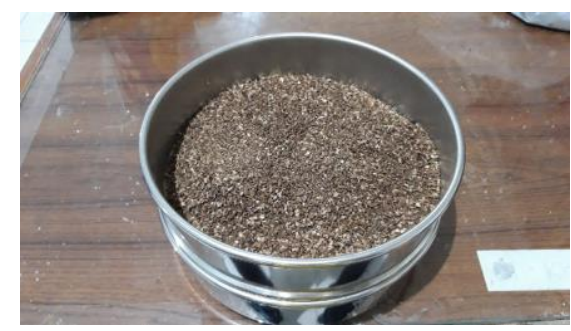

Figure 2 Indonesian Coconut Shell of Kelapa Dalam Bojong Bulat Variety

\subsection{MAP Process}

The effects of power and residence time of the microwave assisted pyrolysis (MAP) on the biochar yield were exhibited in Figure 3. On the other hand, the correlation between the temperature of MAP and the residence time for different microwave power is shown in Figure 4.

Figure 4 revealed that the reaction temperatures were ranging from $126{ }^{\circ} \mathrm{C}$ to $205.4{ }^{\circ} \mathrm{C}$. The lower residence time and microwave power led to the lower reaction temperature. Furthermore, Figure 3 demonstrated that power and reaction time of MAP resulted in significant impact on the coconut shell biochar yield. It can be observed in Figure 3 that MAP process conducted at the power of $550 \mathrm{~W}$ for 15,20 , and 25 minutes provided $91.31-70.12 \mathrm{wt} \%$ of coconut shell biochar. However, when the power level of microwave was stepped up to $600 \mathrm{~W}$ and $650 \mathrm{~W}$, the coconut shell biochar yields were decreasing with the increase of power and reaction time. It can be inferred that biochar yield decreased with the power and residence time of MAP. It was due to the fact that the higher power of microwave was also correlated with the rapid increasing of the reaction temperature. Pyrolysis caused the thermal degradation of coconut shells into gas, liquid, and char products. As depicted in Figure 4, the higher power and the longer residence time indicated the higher reaction temperature. The higher reaction temperature will initiate the higher degradation of raw material (lingo-cellulosic biomass), shifting the reaction to generate more liquid and gas products rather than solid product and reducing the biochar yield [26].

The coconut shell biochar produced in this work is shown in Figure 5. The optimal yield was provided by the MAP process conducted at $550 \mathrm{~W}$ with the residence time of 15 and 20 minutes, resulting in yield of $91.31 \mathrm{wt} \%$ of biochar (called as S1) and $83.88 \mathrm{wt} \%$ biochar (called as S2), respectively. Biochar yield obtained in this work were higher than biochar produced through the conventional method or other pyrolysis technologies as presented in Table 2, indicating the advantage and potential of MAP in biomass conversion.

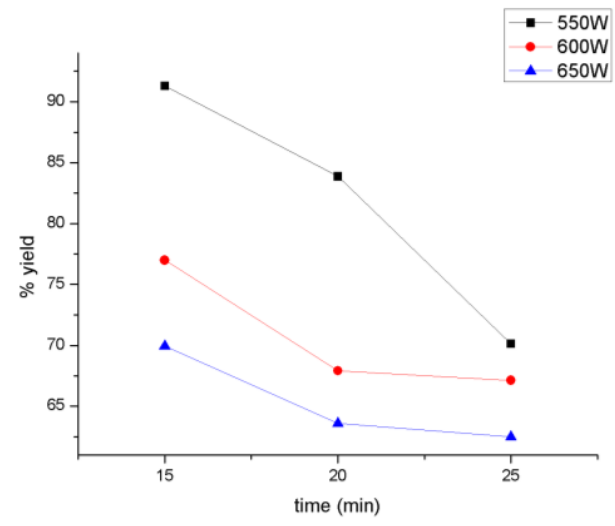

Figure 3 The Effects of Power and Reaction Time of the Microwave Assisted Pyrolysis on the Coconut Shell Biochar Yield 


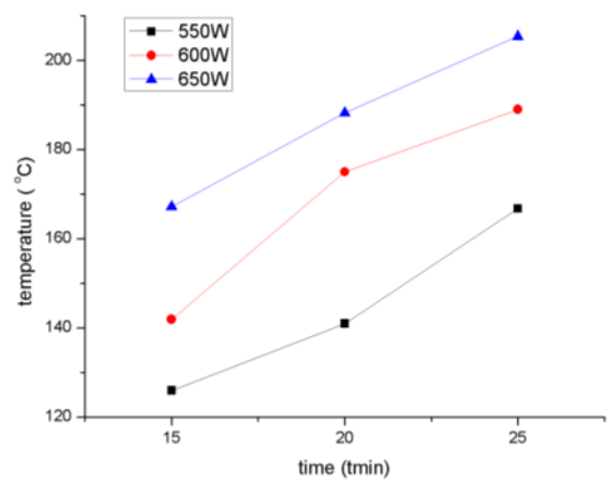

Figure 4 Correlation of the Temperature with the Microwave Assisted Pyrolysis Residence Time

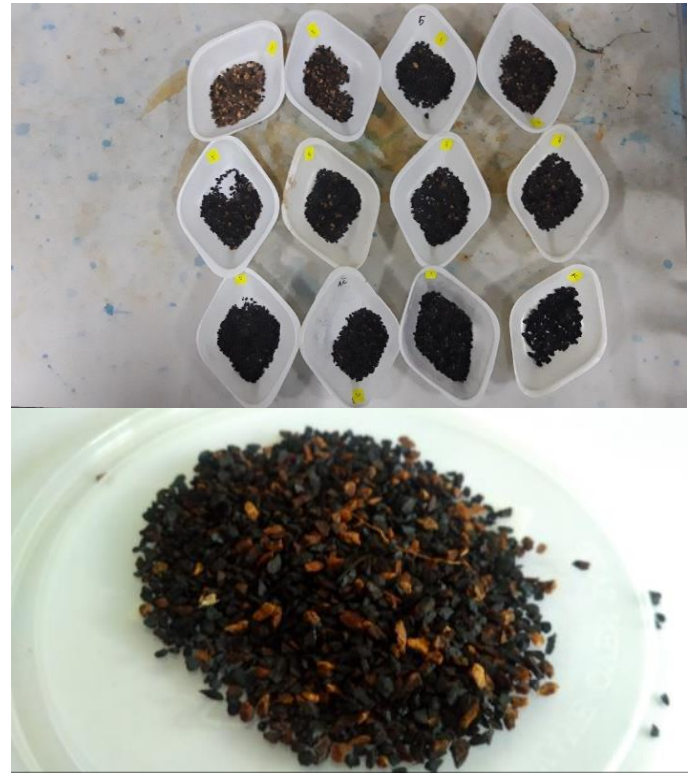

Figure 5 Coconut Shell Biochar (CSB)

Table 2 Comparison of Biochar Yield from Biomass Using Various Pyrolysis Technologies

\begin{tabular}{|c|c|c|c|c|c|c|}
\hline Material & Method & $\begin{array}{c}\text { Temperature, } \\
{ }^{\circ} \mathrm{C} \\
\end{array}$ & Time, & $\begin{array}{l}\text { Heating Rate, } \\
{ }^{\circ} \mathrm{C} / \mathrm{min}\end{array}$ & $\begin{array}{c}\text { Yield, } \\
\%\end{array}$ & Ref. \\
\hline Coconut shell & $\begin{array}{l}\text { Slow pyrolysis } \\
\text { (tube furnace) }\end{array}$ & 600 & & 5 & 28.2 & {$[21]$} \\
\hline Coconut shell & $\begin{array}{l}\text { Pyrolysis by } \\
\text { electrical furnace }\end{array}$ & $400-600$ & & 20 & $32-25.4$ & [27] \\
\hline Coconut shell & $\begin{array}{l}\text { Conventional slow } \\
\text { pyrolysis (drum kiln } \\
\text { furnace) }\end{array}$ & & $5 \mathrm{~h}$ & & 30.1 & [28] \\
\hline Coconut shell & Slow pyrolysis & 700 & $1 \mathrm{~h}$ & & 27.6 & [29] \\
\hline $\begin{array}{l}\text { Medium density } \\
\text { fibreboard }\end{array}$ & $\begin{array}{l}\text { Conventional } \\
\text { pyrolysis }\end{array}$ & $350-450$ & & & $28.4-27$ & [14] \\
\hline $\begin{array}{l}\text { Empty fruit } \\
\text { bunches }\end{array}$ & $\begin{array}{c}\text { electric furnace } \\
\text { heated }\end{array}$ & $300-700$ & & 30 & $42-23$ & [30] \\
\hline Coconut shell & $\begin{array}{c}\text { Microwave } \\
\text { Assisted Pyrolysis }\end{array}$ & $126-205.4$ & $\begin{array}{l}15-25 \\
\min \end{array}$ & & $\begin{array}{c}62.49- \\
91.31\end{array}$ & This Work \\
\hline
\end{tabular}


Additionally, the 9 samples of biochars which were resulted at the different microwave power and residence time (S1, S2, S3, S4, S5, S6, S7, S8, and S9) were then underwent adsorption test using methylene blue solution to determine their adsorption efficiency.

\subsection{Adsorption Test}

Adsorption test was conducted using methylene blue dyes on the 9 samples of coconut shell biochar ( $\$$ 1, S2, S3, S4, S5, S6, S7, S8, and S9) which were produced at the different microwave power and reaction time. Solution adsorbed using commercial activated carbon was used as the positive (+) control. On the other hand, solution which didn't undergo adsorption treatment was utilized as the negative control. The effectiveness percentage of the adsorption was calculated based on the initial and final concentration of methylene blue in the adsorption process. The adsorption effectiveness of each sample was presented in Figure 6.

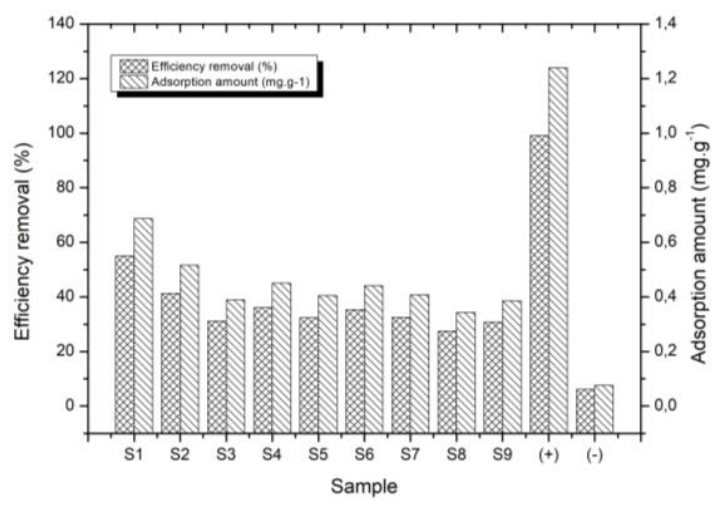

Figure 6 Adsorption effectiveness of bio char samples

Figure 6 exhibits that the highest adsorption were provided by the positive control (commercial activated carbon), S1, and S2 with the amount of methylene blue adsorbed were $1.2396 \mathrm{mg}^{-1} \mathrm{~g}^{-1}, 0.6875$ $\mathrm{mg} \cdot \mathrm{g}^{-1}$, and $0.5165 \mathrm{mg}^{-1}$, respectively and the adsorption efficiency were $99.17 \%, 55.00 \%$ and $41.32 \%$. Therefore, those two types of coconut shell biochar (S1 and S2) were characterized using FTIR, FESEM, and BET to disclose their properties.

\subsection{Characterization}

\subsubsection{Fourier Transform Infrared (FTIR)}

The infrared spectra for CS (coconut shell raw material), S1 (sample 1 of biochar), S1' (sample 1 of biochar after being used for the adsorption test), s2 (sample 2 of biochar), S2' (sample 2 of biochar after being used for the adsorption test) are shown in Figure 7, which indicate the wavelength absorption representing the presence of different oxygen groups, especially carbonyl groups, alcohols and phenols, ethers and esters.

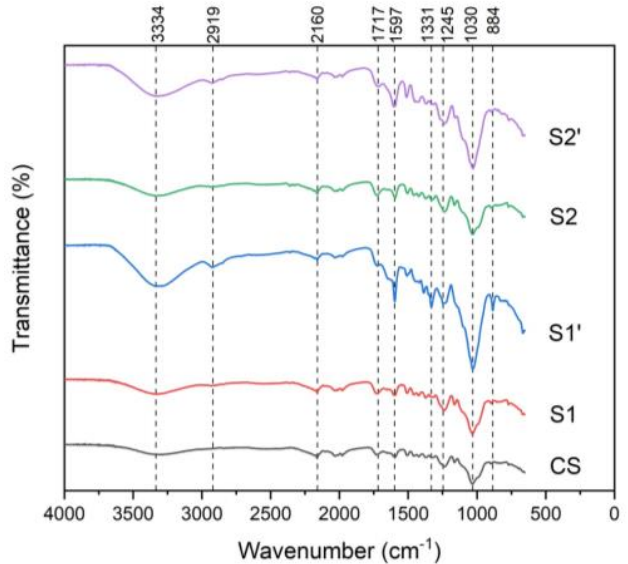

Figure 7 Infrared Spectra of the coconut shell raw material and biochar

Based on the observation, the band with the width in the range of $3400-2800 \mathrm{~cm}^{-1}$ referred to the hydrogen bond. Adsorption on $3334 \mathrm{~cm}^{-1}$ was strongly correlated to the dimer $-\mathrm{OH}$ group of carboxylic acid. On the other hand, the band with the width of $2919 \mathrm{~cm}^{-1}$ was designated the stretching vibration of the $\mathrm{C}-\mathrm{H}$ bond of the methyl and methylene groups. The peaks on $2160 \mathrm{~cm}^{-1}$ and 2035 $\mathrm{cm}^{-1}$ were associated with the various stretching of $\mathrm{C}-\mathrm{H}$ and iso-cyanide. Adsorption band near to 1717 $\mathrm{cm}^{-1}$ was in accordance with the stretching vibration of $\mathrm{C}=\mathrm{O}$ of the ketone, carboxylic acid, and ester. Spectra denoting the stretching of $\mathrm{C}-\mathrm{C}$ aromatics were found on $1597 \mathrm{~cm}^{-1}$ and $1507 \mathrm{~cm}^{-1}$. On the other hand, the $1597 \mathrm{~cm}^{-1}$ peak may point to the carboxylic acid of the stretching vibration of $\mathrm{C}-\mathrm{O}$.

Coconut shell raw material, biochar sample 1 (S1) and biochar sample 2 (S2) showed the stretching of C-C aromatics on the $1458 \mathrm{~cm}^{-1}$. However, after being used for the adsorption process, it can be found that the spectra shifted and merged to 1442 $\mathrm{cm}^{-1}$, which was defined as the deformation vibration of $-\mathrm{CH}_{2}$. Spectra indicating the various nitrogen compounds were shown on $1331 \mathrm{~cm}^{-1}$, which was correlated to the stretching of $\mathrm{N}-\mathrm{O}$. Peak on 1247 $\mathrm{cm}^{-1}$ is related to the C-O stretching of esters or carboxylic acid. Sharp band can be observed on the wave number of $1320-1000 \mathrm{~cm}^{-1}$, with the peak on $1030 \mathrm{~cm}^{-1}$. It specified the stretching vibration of $\mathrm{C}-\mathrm{O}$ of esters or carboxylic acid. C-H out-of-plane band was also found on the $884 \mathrm{~cm}^{-1}$ peak. On the other hand, 827 and $768 \mathrm{~cm}^{-1}$ peaks were closely correlated with the $\mathrm{C}-\mathrm{H}$ aromatics group. The similar functional groups were also discovered in the various products of biochar as reported in the literatures [22], [23], [31], [27]. It proved that the biochar has been formed during the pyrolysis process using MAP.

Several peaks after the adsorption process in this FTIR results may be found to be shifting compared to biochar sample before adsorption process. This phenomenon occurred due to the adsorbentadsorbate interaction $[32,33]$. The hydroxyl $(\mathrm{OH})$ and carbonyl $(C=O)$ found on the biochars surface 
possibly involved in the methylene blue adsorption mechanism [34].The reduction of peak intensity can also be associated to the degradation of hemicelluloses structure [35].

\subsubsection{Field Emission Scanning Electron Microscope (FESEM)}

Characterization using FESEM was conducted for the raw material, biochar S1, and biochar S2 before and after being employed for the methylene blue adsorption process. The FESEM analysis results for the coconut shell, biochar S1 before the adsorption, biochar S1 after the adsorption, biochar S2 before the adsorption, and biochar $\$ 2$ after the adsorption were shown in Figures 8, 9 and 10, respectively.

It was depicted that the different power and pyrolysis residence time brought about the different effects on the biochar surface. However, biochar sample 1 (S1) and 2 (S2) showed a slight dissimilarity with the coconut shell raw material surface as presented in Figure 8, 9a, and 10a. It was revealed that converting coconut shell raw material into biochars could increase the pores size and make them more uniform [36].

The FESEM images on Figure 9 (a) and 10 (a) revealed that the surface of biochars before adsorption (S1 and S2) show porous surface with irregular pore shape. After the adsorption process, the number of pore was reduced. The gaps on the biochar surface were partially disappearing. It denotes that the pores were locked by the methylene blue molecule, indicating the effectiveness of the adsorption process of methylene blue on the biochar surface. This phenomena agrees with the work of Jawad et al. [34].

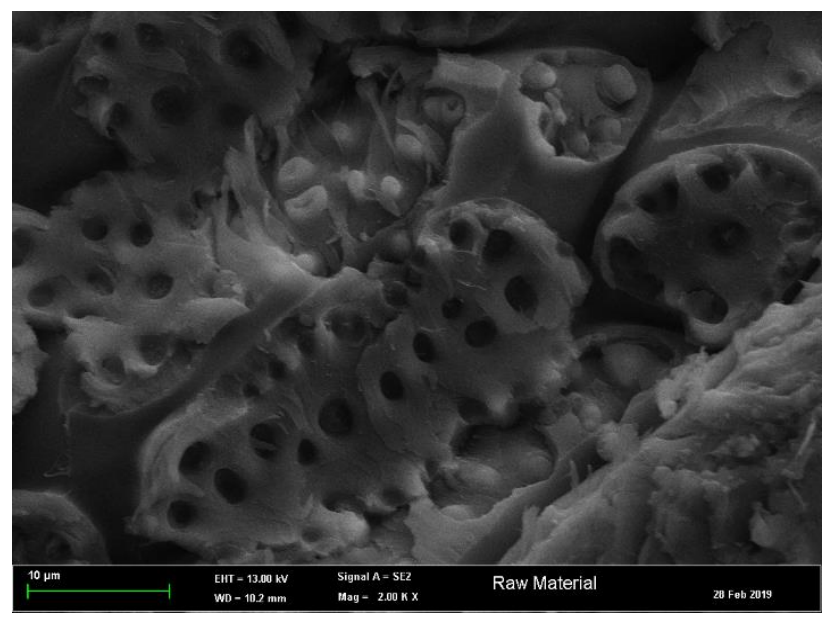

Figure 8 Micrograph of raw coconut shell at 2000x magnification

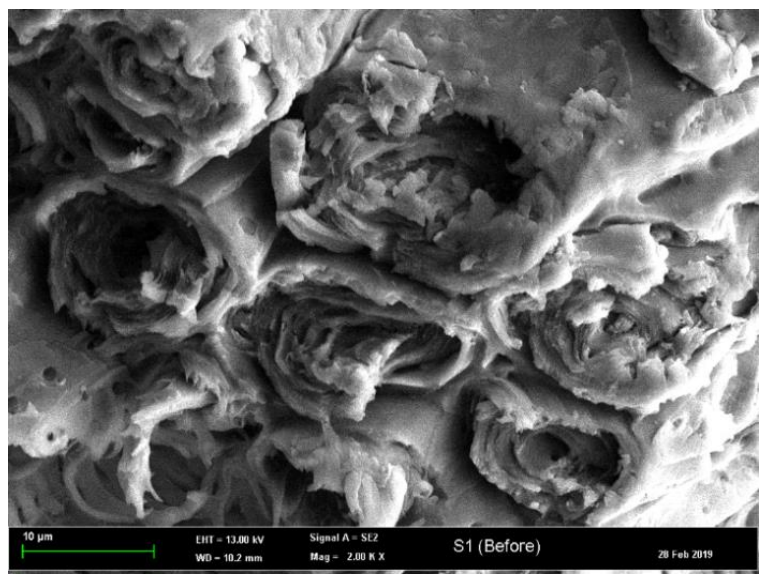

(a)

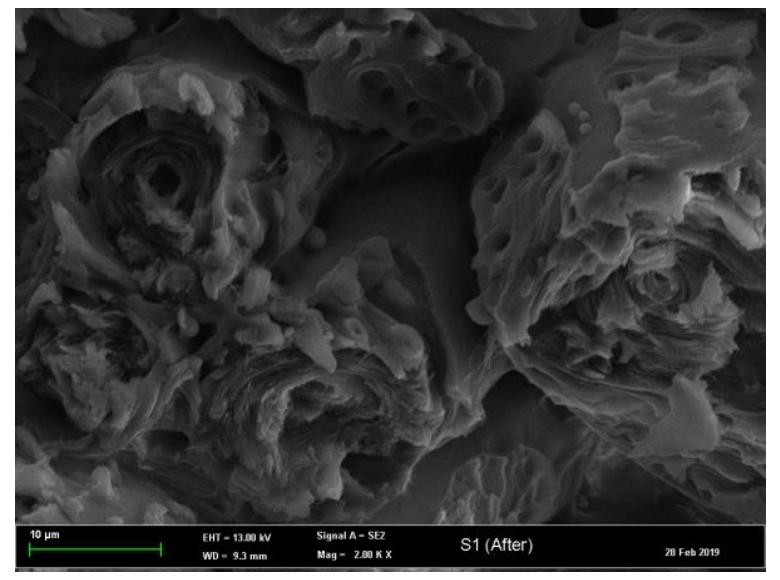

(b)

Figure 9 Micrograph of biochar-S1 (a) before and (b) after MB Adsorption at 2000x magnification 


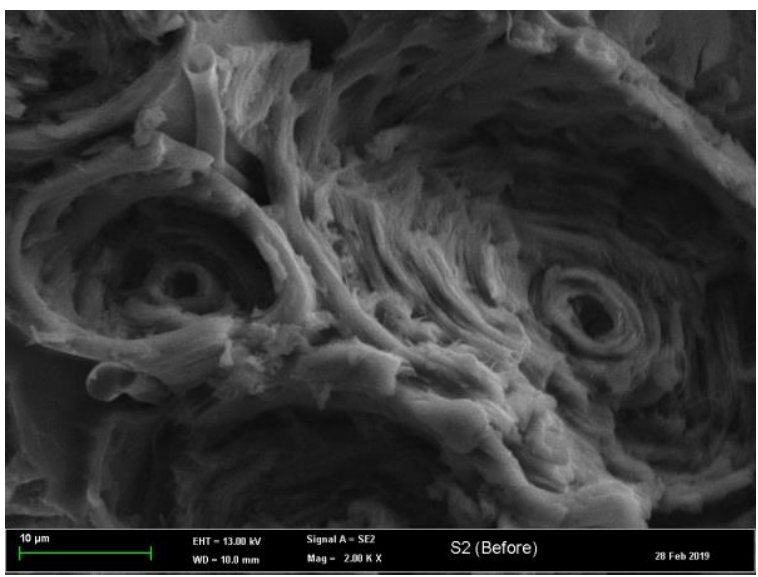

(a)

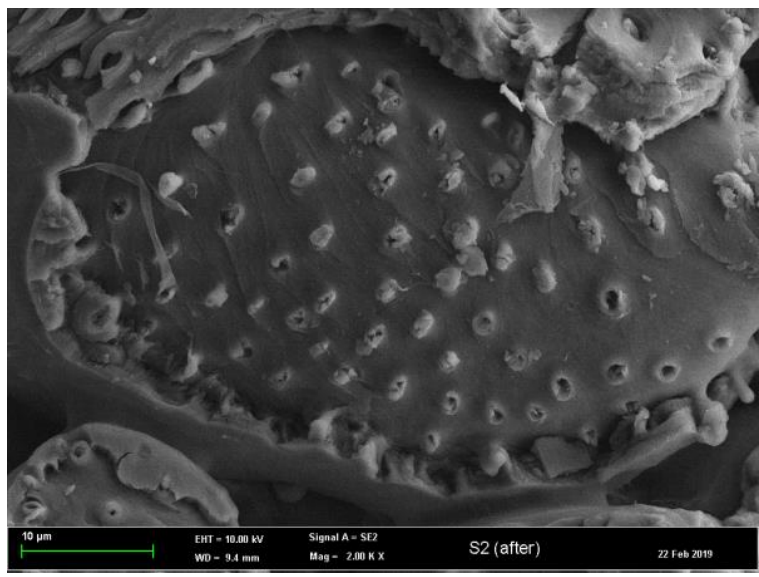

(b)

Figure 10 Micrograph of biochar-S2(a) before and (b) after MB Adsorption at 2000x magnification

\subsubsection{Brunauer-Emmett-Teller (BET)}

BET analysis was conducted to determine the surface area, pore area, and pore volume of the biochar. The adsorption-desorption isotherm for the biochar sample 1 (S1) and sample 2 (S2) are demonstrated in Figures 11 and 12. BET analysis is carried out by measuring the adsorption isotherm of the nitrogen gas. Based on the BET analysis, it was revealed that surface area of the raw material (coconut shell), sample 1 (S1) and sample 2 (S2) biochars were 0.4042 $\mathrm{m}^{2} . \mathrm{g}^{-1}, 0.1983 \mathrm{~m}^{2} . \mathrm{g}^{-1}$ and $0.4519 \mathrm{~m}^{2} . \mathrm{g}^{-1}$, respectively. It denoted that the longer residence time of MAP process would result in the higher surface area of biochar. Generally, temperature of process is the main factor affecting the surface area of biochar. In the microwave assisted reaction, the higher residence time also correlates with the higher temperature of reaction, which implied on the higher surface area of the material [37]. The longer time of the pyrolysis process will provide more possibility of the microwave radiation absorption on the material which enhanced the surface area of biochar. Additionally, the surface area has strong correlation with the porosity. During the pyrolysis process of biomass, volatile compounds will leave the material and form the pores. The higher porosity of the biochar surface was triggered by the increasing pressure inside the raw material as the consequence of the fast heating. Once the volatile matter detached from the inside part of the particle, the porosity of the biochar surface will increase and leads to the increasing surface area [38].

The BET analysis also enables to determine the pore area and pore volume of the mesopore and micropore of biochar. Surface area and porosity of raw material (coconut shell) and biochars are presented in Table 3.

The BET test has exhibited that the biochar pores consisted of the micro and meso types of pores. Table 3 show that biochar S1 which has higher surface areas of micropore and mesopore adsorbed a higher amount of methylene blue dye (55.00\%) than biochar S2 (41.32\%). The rough texture and the heterogeneous distribution of the pores of the biochar becomes evidence that biochar is useful for the liquid adsorption, such as water treatment.

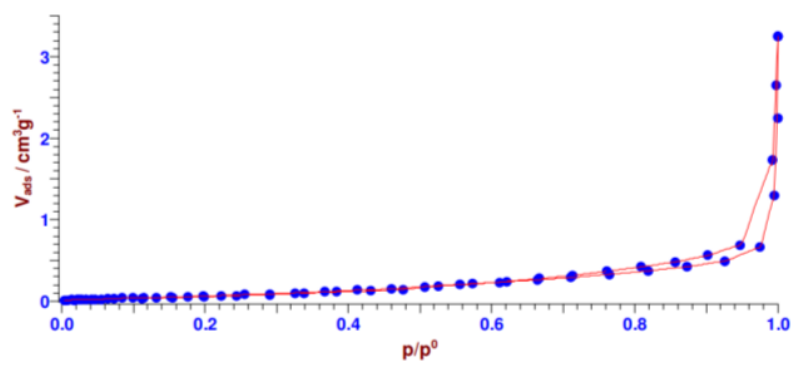

Figure 11 BET Adsorption-Desorption Isotherm of Biochar Sample 1 (S1)

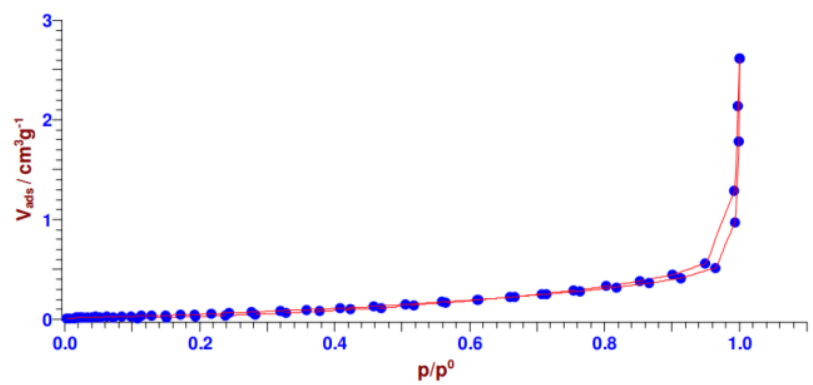

Figure 12 BET Adsorption-Desorption Isotherm of Biochar Sample 2 (S2)

The pore diameter of biochars were also adequate for the methylene blue dye adsorption. The molecular size of methylene blue is $1.43 \mathrm{~nm} \times 0.61$ $\mathrm{nm} \times 0.4 \mathrm{~nm}$ [39] or similar to $3.489 \times 10^{-18} \mathrm{~cm}^{3}$ which can be adsorbed using biochar. Other literature stated that the methylene blue molecular length is $1.382 \mathrm{~nm}$ or $1.447 \mathrm{~nm}$, with width about $0.95 \mathrm{~nm}$. The difference of the length is determined by the 
location of chlorine ion on the methylene blue molecule. The chlorine ion can be linked to the intermediate sulfur in the center of molecule, or it is connected to the two nitrogen atoms at side. Comparing the methylene blue molecule size and the pore diameter of biochars, it can be inferred that the coconut shell biochar pores are viable for methylene blue adsorption [40].

Table 3 Surface Area and Porosity of Biochars

\begin{tabular}{lcccc}
\hline Parameter & Unit & $\begin{array}{c}\text { Coconut } \\
\text { Shell }\end{array}$ & $\begin{array}{c}\text { Biochar } \\
\text { S1 }\end{array}$ & $\begin{array}{c}\text { Biochar } \\
\text { S2 }\end{array}$ \\
\hline $\begin{array}{l}\text { Specific } \\
\text { Surface Area }\end{array}$ & $\mathrm{m}^{2} \cdot \mathrm{g}-1$ & 0.4042 & 0.1991 & 0.4556 \\
$\begin{array}{l}\text { Pore Volume } \\
\text { Pore }\end{array}$ & $\mathrm{cm}^{3} \cdot \mathrm{g}-1$ & 0.0028 & 0.0018 & 0.0014 \\
$\begin{array}{l}\text { Diameter } \\
\text { Mesopore }\end{array}$ & $\mathrm{nm}$ & 27.65 & 36.30 & 12.39 \\
$\begin{array}{l}\text { Volume } \\
\text { Area }\end{array}$ & & & & \\
$\begin{array}{l}\text { Micropore } \\
\text { Volume }\end{array}$ & $\mathrm{cm}^{3} \cdot \mathrm{g}-1$ & 0.0058 & 0.0043 & 0.0035 \\
Area & $\mathrm{m}^{2} \cdot \mathrm{g}-1$ & 0.8353 & 0.6563 & 0.5741 \\
& $\mathrm{~cm}^{3} \cdot \mathrm{g}-1$ & 0.0005 & 0.00033 & 0.00026 \\
& $\mathrm{~m}^{2} \cdot \mathrm{g}-1$ & 1.3956 & 0.916 & 0.7294 \\
\hline
\end{tabular}

However, the specific surface areas of the biochars obtained in this research were lower than those exhibited by the other studies. Chahinez et al. reported that biochar derived from palm petiole exhibited specific surface area of $640 \mathrm{~m}^{2} \cdot \mathrm{g}^{-1}$ by the pyrolysis at $700^{\circ} \mathrm{C}$ [41]. Lawal et al. described that biochar synthesized via steam pyrolysis of oil palm frond at $500^{\circ} \mathrm{C}$ followed by the pulverization process resulted in the specific surface area of $406.6 \mathrm{~m}^{2} . \mathrm{g}^{-1}$ [42]. On the other hand, Razali et al. found the specific surface area of biochar produced from the palm oil trunk pyrolysis at $950^{\circ} \mathrm{C}$ was $95.92 \mathrm{~m}^{2} \cdot \mathrm{g}^{-1}$ [43]. Caballero et al. demonstrated that the specific surface area of biochar produced from coconut shell waste pyrolysis were ranging from 9.8468 - 15.7544 $\mathrm{m}^{2} \cdot \mathrm{g}^{-1}$ for the pyrolysis temperature of $280-420^{\circ} \mathrm{C}$ [44]. It can be suggested that the specific surface area of biochar can be increased by raising the pyrolysis temperature. In the case of microwaveassisted pyrolysis, the increasing of the temperature is intensely correlated with the microwave power.

In addition, it was known that biochar is characterized by low surface area. Hence, to increase its capacity as adsorbent, it is beneficial to conduct the activation process using chemical such as sodium carbonate [45]. Besides, the post physical treatment such as ultrasound treatment [46] and pulverization is also beneficial since it help to create new external surface area [42].

\subsection{CONCLUSION}

It can be concluded that coconut shell can be used as raw material to produce biochar which can be applied as adsorbent to remove dyes such as methylene blue from solution. Microwave pyrolysis was also demonstrated as a useful technique to convert coconut shell to biochar. Coconut shell biochars (S1and S2) revealed good adsorption capacity in which the amounts of methylene blue

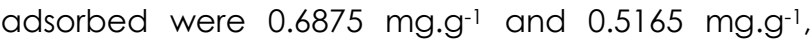
respectively. On the other hand, the adsorption efficiencies of S1 and S2 were $55.00 \%$ and $41.32 \%$, respectively. However, coconut shell biochar performance on methylene blue adsorption should be improved since it was lower than commercial carbon active which provided adsorption capacity of $1.2396 \mathrm{mg}^{-1} \mathrm{~g}^{-1}$ with the efficiency of $99.17 \%$,

\section{Acknowledgement}

The research grant provided by the Ministry of Research, Technology, and Higher Education of Republic Indonesia through the Basic Research Grant (Penelitian Dasar) with Contract Number 48.18.3/UN37/PPK.3.1/2019 as well as the funding from the Ministry of Higher Education Malaysia through the Research University Grants (4F994 and 07G78) are acknowledged.

\section{References}

[1] Statistik, B. P. 2016. Statistical Yearbook of Indonesia 2016. (S. of S. C. and Publication, Ed.). Jakarta: BPS-Statistics Indonesia.

[2] Mulyawan, M., Setyowati, E., \& Wijaya, A. 2015. Surfaktan Sodium Ligno Sulfonat (SLS) dari Debu Sabut Kelapa. Jurnal Teknik ITS. 4(1): 1-3.

[3] Gao, Y., Yang, Y., Qin, Z., \& Sun, Y. 2016. Factors Affecting the Yield of Bio-oil from the Pyrolysis of Coconut Shell. SpringerPlus. 5(1). https://doi.org/10.1186/s40064-016-19742.

[4] Fardhyanti, D. S., Megawati, Kurniawan, C., Sigit Lestari, R. A., \& Triwibowo, B. 2018. Producing Bio-oil from Coconut Shell by Fast Pyrolysis Processing. MATEC Web of Conferences. 237

$0-4$ https://doi.org/10.1051/matecconf/201823702001.

[5] Kumar, V. R. P., Gunasekaran, K., \& Shyamala, T. 2019. Characterization Study on Coconut Shell Concrete with Partial Replacement of Cement by GGBS. Journal of Building Engineering. 26(March): 100830. https://doi.org/10.1016/j.jobe.2019.100830.

[6] Sinsinwar, S., Sarkar, M. K., Suriya, K. R., Nithyanand, P., \& Vadivel, V. 2018. Use of Agricultural Waste (Coconut Shell) for the Synthesis of Silver Nanoparticles and Evaluation of Their Antibacterial Activity Against Selected Human Pathogens. Microbial Pathogenesis. 124(July): 30-37. https://doi.org/10.1016/j.micpath.2018.08.025.

[7] Granados-Fitch, M. G., Quintana-Melgoza, J. M., JuarezArellano, E. A., \& Avalos-Borja, M. 2019. Mechanism to H 2 Production on Rhenium Carbide from Pyrolysis of Coconut Shell. International Journal of Hydrogen Energy. 44(5): 2784-2796. https://doi.org/10.1016/j.ijhydene.2018.12.042.

[8] Yahaya, A. Z., Somalu, M. R., Muchtar, A., Sulaiman, S. A., \& Wan Daud, W. R. 2019. Effect of Particle Size and Temperature on Gasification Performance of Coconut and Palm Kernel Shells in Downdraft Fixed-bed Reactor. Energy. $\quad$ 175: 931-940. https://doi.org/10.1016/j.energy.2019.03.138.

[9] Sanni, E. S., Emetere, M. E., Odigure, J. O., Efeovbokhan, V. E., Agboola, O., \& Sadiku, E. R. 2017. Determination of 
Optimum Conditions for the Production of Activated Carbon Derived from Separate Varieties of Coconut Shells. International Journal of Chemical Engineering. 2017. https://doi.org/10.1155/2017/2801359.

[10] Muvhiiwa, R., Kuvarega, A., Llana, E. M., \& Muleja, A. (2019). Study of Biochar from Pyrolysis and Gasification of Wood Pellets in a Nitrogen Plasma Reactor for Design of Biomass Processes. Journal of Environmental Chemical Engineering. $7(5):$ 103391. https://doi.org/10.1016/j.jece.2019.103391.

[11] Abas, F. Z., \& Ani, F. N. 2014. Comparing Characteristics of Oil Palm Biochar Using Conventional and Microwave Heating. Jurnal Teknologi (Sciences and Engineering). 68(3): 33-37. https://doi.org/10.11113/jt.v68.2926.

[12] Shukla, N., Sahoo, D., \& Remya, N. 2019. Biochar from Microwave Pyrolysis of Rice Husk for Tertiary Wastewater Treatment and Soil Nourishment. Journal of Cleaner Production. 235: 1073-1079. https://doi.org/10.1016/j.jclepro.2019.07.042

[13] Reddy, B. R., Shravani, B., Das, B., Dash, P. S., \& Vinu, R. 2019. Microwave-assisted and Analytical Pyrolysis of Coking and Non-coking Coals: Comparison of Tar and Char Compositions. Journal of Analytical and Applied Pyrolysis. 142(September 2018): 104614 https://doi.org/10.1016/j.jaap.2019.05.003.

[14] Haeldermans, T., Claesen, J., Maggen, J., Carleer, R., Yperman, J., Adriaensens, P., ... Schreurs, S. 2019. Microwave Assisted and Conventional Pyrolysis of MDF Characterization of the Produced Biochars. Journal of Analytical and Applied Pyrolysis. 138(October 2018): 218230. https://doi.org/10.1016/j.jaap.2018.12.027.

[15] Wu, L., Zhou, J., Zhou, J., Liang, K., Song, Y., Zhang, Q., \& Tian, Y. 2019. Temperature-rising Characteristics and Product Analysis of Low-rank Coal Microwave Pyrolysis under $\mathrm{CH} 4$ Atmosphere. Journal of Analytical and Applied Pyrolysis. 141 (March): https://doi.org/10.1016/j.jaap.2019.104632.

[16] Lam, S. S., Azwar, E., Peng, W., Tsang, Y. F., Ma, N. L., Liu, Z., ... Kwon, E. E. 2019. Cleaner Conversion of Bamboo Into Carbon Fibre with Favourable Physicochemical and Capacitive Properties Via Microwave Pyrolysis Combining with Solvent Extraction and Chemical Impregnation. Journal of Cleaner Production. 236: 117692. https://doi.org/10.1016/j.jclepro.2019.117692.

[17] Lam, S. S., Wan Mahari, W. A., Ma, N. L., Azwar, E., Kwon, E. E., Peng, W., ... Park, Y. K. 2019. Microwave Pyrolysis Valorization of Used Baby Diaper. Chemosphere. 230: 294302. https://doi.org/10.1016/j.chemosphere.2019.05.054.

[18] Bu, Q., Chen, K., Xie, W., Liu, Y., Cao, M., Kong, X., ... Mao, H. 2019. Hydrocarbon Rich Bio-oil Production, Thermal Behavior Analysis and Kinetic Study of Microwave-assisted Co-pyrolysis of Microwave-torrefied Lignin with Low Density Polyethylene. Bioresource Technology. 291 (July): 121860. https://doi.org/10.1016/j.biortech.2019.121860.

[19] Abas, F. Z., Ani, F. N., \& Zakaria, Z. A. 2018. Microwaveassisted Production of Optimized Pyrolysis Liquid Oil from Oil Palm Fiber. Journal of Cleaner Production. 182: 404413. https://doi.org/10.1016/j.jclepro.2018.02.052.

[20] Kostas, E. T., Williams, O. S. A., Duran-Jimenez, G., Tapper, A. J., Cooper, M., Meehan, R., \& Robinson, J. P. 2019. Microwave Pyrolysis of Laminaria Digitata to Produce Unique Seaweed-derived Bio-oils. Biomass and Bioenergy. 125(October 2018): 41-49. https://doi.org/10.1016/j.biombioe.2019.04.006.

[21] Windeatt, J. H., Ross, A. B., Williams, P. T., Forster, P. M. Nahil, M. A., \& Singh, S. 2014. Characteristics of Biochars from Crop Residues: Potential for Carbon Sequestration and Soil Amendment. Journal of Environmental Management. 146: 189-197. https://doi.org/10.1016/j.jenvman.2014.08.003

[22] Islam, M. A., Ahmed, M. J., Khanday, W. A., Asif, M., \& Hameed, B. H. 2017. Mesoporous Activated Coconut Shell-derived Hydrochar Prepared via Hydrotherma Carbonization- $\mathrm{NaOH}$ Activation for Methylene Blve
Adsorption. Journal of Environmental Management. 203: 237-244. https://doi.org/10.1016/j.jenvman.2017.07.029.

[23] Yang, K., Peng, J., Srinivasakannan, C., Zhang, L., Xia, H., \& Duan, X. 2010. Preparation of High Surface Area Activated Carbon from Coconut Shells Using Microwave Heating. Bioresource Technology. 101(15): 6163-6169. https://doi.org/10.1016/j.biortech.2010.03.001.

[24] Xin, Y., Wang, D., Li, X. Q., Yuan, Q., \& Cao, H. 2018. Influence of Moisture Content on Cattle Manure Char Properties and Its Potential for Hydrogen Rich Gas Production. Journal of Analytical and Applied Pyrolysis. 130: 249-255. https://doi.org/10.1016/j.jaap.2018.01.005.

[25] Enders, A., Hanley, K., Whitman, T., Joseph, S., \& Lehmann, J. 2012. Characterization of Biochars to Evaluate Recalcitrance and Agronomic Performance. Bioresource Technology. 114:

644-653. https://doi.org/10.1016/j.biortech.2012.03.022.

[26] Huang, Y. F., Chiveh, P. Te, Kuan, W. H., \& LO, S. L. 2015. Effects of Lignocellulosic Composition and Microwave Power Level on the Gaseous Product of Microwave Pyrolysis. Energy. 89: 974-981. https://doi.org/10.1016/j.energy.2015.06.035.

[27] Rout, T., Pradhan, D., Singh, R. K., \& Kumari, N. 2016. Exhaustive Study of Products Obtained from Coconut Shell Pyrolysis. Journal of Environmental Chemical Engineering. 4(3). https://doi.org/10.1016/j.jece.2016.02.024.

[28] Hariz, A. R. M. Azlina, W. A. K. G. W. Fazly, M. M. \& Norziana, Z. Z. 2015. Local Practices for Production of Rice Husk Biochar and Coconut Shell Biochar: Production Methods, Product Characteristics, Nutrient and Field Water Holding Capacity. Journal of Tropical Agriculture and Food Science. 43(1): 91-101.

[29] Lima, I. M., Boateng, A. A., \& Klasson, K. T. 2009. Pyrolysis of Broiler Manure: Char and Product Gas Characterization. Industrial and Engineering Chemistry Research. 48(3): 1292-1297. https://doi.org/10.1021/ie800989s.

[30] Sukiran, M. A., Kheang, L. S., Bakar, N. A., \& May, C. Y. 2011. Production and Characterization of Bio-char from the Pyrolysis of Empty Fruit Bunches. American Journal of Applied Sciences. 8(10): 984-988. https://doi.org/10.3844/ajassp.2011.984.988.

[31] Liu, Y., Zhao, X., Li, J., Ma, D., \& Han, R. 2012. Characterization of Bio-char from Pyrolysis of Wheat Straw and Its Evaluation on Methylene Blue Adsorption. Desalination and Water Treatment. 46(1-3): 115-123. https://doi.org/10.1080/19443994.2012.677408.

[32] Dinh, V. P., Huynh, T. D. T., Le, H. M., Nguyen, V. D., Dao, V. A., Hung, N. Q., ... Tan, L. V. 2019. Insight into the Adsorption Mechanisms of Methylene Blue and Chromium(III) from Aqueous Solution onto Pomelo Fruit Peel. RSC Advances. 9(44): 25847-25860. https://doi.org/10.1039/c9ra04296b.

[33] Ait Ahsaine, H., Anfar, Z., Zbair, M., Ezahri, M., \& El Alem, N. 2018. Adsorptive Removal of Methylene Blue and Crystal Violet onto Micro-mesoporous $\mathrm{Zr} 3$ O/activated Carbon Composite: A Joint Experimental and Statistical Modeling Considerations. Journal of Chemistry. 2018. https://doi.org/10.1155/2018/6982014.

[34] Jawad, A. H., Abdulhameed, A. S., \& Mastuli, M. S. 2020 Acid-factionalized Biomass Material for Methylene Blve Dye Removal: A Comprehensive Adsorption and Mechanism Study. Journal of Taibah University for Science. 14(1): https://doi.org/10.1080/16583655.2020.1736767.

[35] Zubair, M., Mu'azu, N. D., Jarrah, N., Blaisi, N. I., Aziz, H. A., \& A. Al-Harthi, M. 2020. Adsorption Behavior and Mechanism of Methylene Blue, Crystal Violet, Eriochrome Black T, and Methyl Orange Dyes onto Biochar-derived Date Palm Fronds Waste Produced at Different Pyrolysis Conditions. Water, Air, and Soil Pollution. 231(5). https://doi.org/10.1007/s1 1270-020-04595-x.

[36] Jouiad, M., Al-Nofeli, N., Khalifa, N., Benyettou, F., \& Yousef, L. F. 2015. Characteristics of Slow Pyrolysis Biochars Produced from Rhodes Grass and Fronds of Edible Date 
Palm. Journal of Analytical and Applied Pyrolysis. 111: 183190. https://doi.org/10.1016/j.jaap.2014.10.024

[37] Wang, Y., Hu, Y., Zhao, X., Wang, S., \& Xing, G. 2013. Comparisons of Biochar Properties from Wood Material and Crop Residues at Different Temperatures and Residence Times. Energy and Fuels. 27(10): 5890-5899. https://doi.org/10.1021/ef400972z.

[38] Antunes, A. E., Jacob, M. V. Brodie, G., \& Schneider, P. A. 2017. Microwave Pyrolysis of Sewage Biosolids: Dielectric Properties, Microwave Susceptor Role and Its Impact on Biochar Properties. Journal of Analytical and Applied Pyrolysis. https://doi.org/10.1016/j.jaap.2017.11.023.

[39] Li, Y., Du, Q., Liu, T., Peng, X., Wang, J., Sun, J., ... Xia, L. 2013. Comparative Study of Methylene Blue Dye Adsorption onto Activated Carbon, Graphene Oxide, and Carbon Nanotubes. Chemical Engineering Research and Design. $91(2)$ :

361-368. https://doi.org/10.1016/j.cherd.2012.07.007

[40] Jia, P., Tan, H., Liu, K., \& Gao, W. 2018. Removal of Methylene Blue from Aqueous Solution by Bone Char Applied Sciences (Switzerland). 8(10). https://doi.org/10.3390/app8101903.

[41] Chahinez, H.-O., Abdelkader, O., Leila, Y., \& Tran, H. N. 2020. One-stage Preparation of Palm Petiole-derived Biochar: Characterization and Application for Adsorption of Crystal Violet Dye in Water. Environmental Technology \& Innovation. 19: 100872 https://doi.org/10.1016/j.eti.2020.100872.

[42] Lawal, A. A., Hassan, M. A., Farid, M. A. A., Yasim-Anuar, T. A. T., Yusoff, M. Z. M., Zakaria, M. R., ... Shirai, Y. 2020.
Production of Biochar from Oil Palm Frond by Steam Pyrolysis for Removal of Residual Contaminants in Palm Oil Mill Effluent Final Discharge. Journal of Cleaner Production. 265: 121643 https://doi.org/10.1016/j.jclepro.2020.121643.

[43] Razali, N., \& Kamarulzaman, N. Z. 2020. Chemical Characterizations of Biochar from Palm Oil Trunk for Palm Oil Mill Effluent (POME) Treatment. Materials Today: Proceedings. https://doi.org/10.1016/j.matpr.2020.02.219.

[44] Castilla-Caballero, D., Barraza-Burgos, J., Gunasekaran, S., Roa-Espinosa, A., Colina-Márquez, J., Machuca-Martínez, F., ... Vázquez-Rodríguez, S. 2020. Experimental Data on the Production and Characterization of Biochars Derived from Coconut-shell Wastes Obtained from the Colombian Pacific Coast at Low Temperature Pyrolysis. Data in Brief. 28: 1-11. https://doi.org/10.1016/j.dib.2019.104855.

[45] Bispo, M. D., Schneider, J. K., Da Silva Oliveira, D., Tomasini, D., Da Silva Maclel, G. P., Schena, T., ... Caramão, E. B. 2018. Production of activated biochar from coconut fiber for the Removal of Organic Compounds from Phenolic. Journal of Environmental Chemical Engineering. 6(2): 2743-2750. https://doi.org/10.1016/j.jece.2018.04.029.

[46] Sencan, A., \& Kiliç, M. 2015. Investigation of the Changes in Surface Area and FT-IR Spectra of Activated Carbons Obtained from Hazelnut Shells by Physicochemical Treatment Methods. Journal of Chemistry. 2015. https://doi.org/10.1155/2015/651651. 